\title{
Landscape-permafrost conditions and factors of summer runoff formation of small coastal lowland rivers
}

\author{
Oleg Tregubov ${ }^{1 *}$, Boris Gartsman ${ }^{2}$, Liudmila Lebedeva $^{3}$, Marina Nuteveket $^{1}$, Anna \\ Tarbeeva ${ }^{4}$, Konstantin Uyagansky ${ }^{1}$, Evgeniy Shekman ${ }^{5}$, and Viktor Shepelev ${ }^{3}$ \\ ${ }^{1}$ North-Eastern Interdisciplinary Scientific Research Institute N.A. Shilo FEB RAS, Portovaya 16, \\ 685000, Magadan, Russia \\ ${ }^{2}$ Water Problems Institute RAS, Gubkina 3, 119333, Moscow, Russia \\ ${ }^{3}$ Melnikov Permafrost Institute SB RAS, Merzlotnaya 36, 677010, Yakutsk, Russia \\ ${ }^{4}$ Lomonosov Moscow State University, Faculty of Geography, Leninskiye Gory 1, 119991, Moscow, \\ Russia \\ ${ }^{5}$ Pacific Geographical Institute FEB RAS, Radio 7, 690041, Vladivostok, Russia
}

\begin{abstract}
River feed and flow regime in the Anadyr lowland remain stable with significant interannual fluctuations in the amount of summer precipitation $(70-180 \mathrm{~mm})$. The lack of summer precipitation is compensated by the suprapermafrost groundwater of the active layer, which is formed by meltwater from seasonal underground ice. In July 2019, complex permafrost-hydrological studies were conducted in the Ugolnaya-Dionisia river basin (Chukotka, Russia) to determine the patterns of formation and dynamics of underground and surface runoff. Seasonal active layer groundwater storage that formed as a result of the melting of seasonal ice was estimated. The territory was classified according to the unite discharge, potential and established water sources. Patterns and factors of seasonal and daily dynamics of the river regime are revealed.
\end{abstract}

\section{Introduction}

One of the challenges of economic expansion into the Arctic and Subarctic areas is limited water resources for water supply of settlements and industry [1]. It is particularly important for the coastal lowlands of North-East Eurasia covered by continuous permafrost. Coastal North-Eastern territories lack any detailed catchment studies. They are situated at the margin of the Arctic and Pacific Oceans drainage basins and characterized by transient climate and permafrost conditions of river runoff generation. In this regard investigations of small-scale mechanisms of streamflow formation at the coastal permafrost-covered lowland rivers are relevant.

The thorough history of hydrological research in the Russian Arctic could be found in the recent paper by Magritsky et al. [2]. The river regime of the studied territory is dominated by spring-summer snow-fed floods, stable winter and variable summer low water periods [3]. Periodicity of summer-autumn floods in the Russian North-East was found in long-term data series [2]. Many researches mention important role of permafrost in

\footnotetext{
*Corresponding author: tregubov2@yandex.ru
} 
the river runoff formation in the studied area [4-6]. Some studies show significance of the active layer for the small rivers feed [7] and the decrease in suprapermafrost flow along with active layer deepening [8; 9]. The complex nonlinear relationships between climate, active layer properties and river runoff are recognized [10]. Earlier, we mentioned that melting of seasonal ground ice of the active layer could potentially contribute water to the small permafrost lowlands rivers [11].

The study aim is to analyze the potential water sources and streamflow regime of small permafrost rivers at the Anadyr lowland in Chukotka.

\section{Materials and methods}

Anadyr lowland, with an area of $35000 \mathrm{~km}^{2}$, is located in the Chukotka Autonomous District within the southern shrub tundra in the lower reaches of the Anadyr, Velikaya and Kanchalan rivers. The climate of the territory is subarctic marine. The mean annual temperature is $-5^{\circ} \mathrm{C}$ (1981-2010). Precipitation amount is about $380 \mathrm{~mm} /$ year, most of which falls in the winter. The permafrost thickness decreases from 300 to $50 \mathrm{~m}$ from north to south of the region. The permafrost temperature at the bottom of the zero annual amplitude increases from -7.1 to $-1{ }^{\circ} \mathrm{C}$ from north to south. The active layer depth in typical lowland landscapes is $45-55 \mathrm{~cm}$.

The studied object is the Ugolnaya-Dionisia River, which was named for coal seam outcrops found at the lower river reaches and the upper right tributary in the north-western spurs of Mount Dionisia. The catchment area is $96 \mathrm{~km}^{2}$. The river length is $24 \mathrm{~km}$. The elevation of the water edge varies from 100 and $180 \mathrm{~m}$ a.s.l. at the upper tributaries to $2.5 \mathrm{~m}$ at the river mouth, which is located on the right bank of the Anadyr estuary. The width of the meandering channel at the lower river is up to $14 \mathrm{~m}$. The depth of the shallow parts of the river is up to $0.6 \mathrm{~m}$. The river valley is $\mathrm{V}$-shaped with a steep left side in the middle course. The width of the floodplain is $20-30 \mathrm{~m}$ in the upper reaches and up to $60 \mathrm{~m}$ in the lower reaches. The floodplain terrace is fragmentary. There are hills with elevation marks of 150-250 $\mathrm{m}$ along the watershed divides (Ostryaya, Kruglyaya, Bolshaya and Malaya). Flattened peaks, extended slopes from 2 to $7 \mathrm{~km}$ long and from 0.75 to $3.5^{\circ}$ steep are found within the catchment. The Ugolnaya-Dionisia River was chosen as the research object due to its location on the border of lowland and mountain tundra. It allows the comparison of water sources for the river in different conditions. Additional data from the CALM site and research plots in the vicinity of the Anadyr city were used.

The research methodology is based on a comparative spatial and temporal analysis of parameters and indicators of the landscape-permafrost diversity of the catchment area. The temporal dynamics was analyzed based on daily data on temperature and moisture content of active layer, river water levels and discharges. From June 26 to July 10, 2019, permafrost-hydrometric survey and monitoring at the key sites were performed. The survey at a scale of 1: 50,000 included the observations of cryogenic processes, description of the soil and vegetation cover, measurements of the soil moisture, thawing depth, river discharges and water sampling for hydrochemical analysis. At key sites, water level and discharge were regularly measured at river gauges, water level and temperature were continuously recorded in pits, soil temperature and moisture were monitored at various depths with 30 minutes time step. Field weather station recorded atmospheric pressure, precipitation, air temperature and humidity. In the first decade of June, before the soil thawing, 10 frozen core samples were taken from the active layer from the surface to $0.5 \mathrm{~m}$ depth at two reference landscape plots in the vicinity of Anadyr city. The ice content was determined in the samples by the temperature-weight method. The mean daily temperature during the field work was $12.1{ }^{\circ} \mathrm{C}$, air humidity $84.3 \%$. Between the snowmelt and the start of work $2.2 \mathrm{~mm}$ of precipitation fell, for the entire observation period $-13 \mathrm{~mm}$. 
We used hydrometric current meter (Potok-mkr GR-100, Potok GR21M), soil moisture meters (TK100-01), portable conductivity meter (COM-80) and $\mathrm{pH}$ meter (KL-911); HOBO ONSET water level (U20L-04), temperature (U23-003) and soil moisture (U23002) data loggers, $5 \times 1200 \mathrm{~mm}$ metal probe and $32 \times 1000 \mathrm{~mm}$ coring pipe. Primary data processing was carried out in accordance with the recommendations of instrument producers. We calculated ice content of the active layer, flow rate, total dissolved solids (TDS) of surface water, time shift of the daily fluctuations extrema of temperature and water levels. Microsoft Excel tools were used for processing the observation data. The Golden Software Surfer was employed to map spatial distribution using Kriging method. The discharge measurements were reassessed as for July 1, 2019 by using discharge time series at the monitored river gauge. The points of determination of the flow rate, TDS, and ice content were taken out to the centres of the corresponding catchments and landscape sections on topographic and landscape maps in the local coordinate system.

\section{Results and discussion}

Permafrost-hydrometric surveys showed mosaic spatial pattern of the thawing depth and soil moisture distribution that generally agreed with the vegetation cover distribution. The thawing depth in the depressions under the moss cover did not exceed 20-25 cm, under the grassy and shrubby vegetation of hummocks - up to 30-35 cm. Mountain tundra at the upper part of the basins was an exception with active layer thickness up to $1-1,5 \mathrm{~m}$. Generally, observed thawing depths correspond to thawing rates calculated from temperature transitions in the active layer: 06/12/19 $(2 \mathrm{~cm})-0.45 \mathrm{~cm} /$ day; 06/26/19 (10 $\mathrm{cm})-1.1 \mathrm{~cm} /$ day; 07/10/19 (30 cm) - $0.8 \mathrm{~cm} /$ day; 07/17/19 (40 cm) - 0.9 cm / day; $08 / 14 / 19(50 \mathrm{~cm})-0.42 \mathrm{~cm} /$ day. Soil moisture at 20-30 cm depth have similar mosaic pattern of spatial distribution. Therefore, these parameters were not used for mapping.

On the contrary, the ice content of the entire section and the upper $30 \mathrm{~cm}$ of the active layer showed typical spatial variability explained by both soil-vegetation cover and the geomorphological features. The maximum ice content of $250-300 \mathrm{~mm}$ was found in the wetlands on the extended $(>1000 \mathrm{~m})$ slopes. Ice content value is recalculated to the water column height. The lowest ice content of 50-150 mm was found at short $(<500 \mathrm{~m})$ and steep slopes and terraces with good drainage and shrub moss-lichen vegetation. The direct ice measurements in the core of shallow wells were used for spatial mapping of the water storages formed by melting of seasonal ice by July 10 (Fig. a).

Different runoff rate allows reasonable distinguishing between mountainous upper part with high runoff rates of more than $15 \mathrm{l} / \mathrm{s} / \mathrm{km}^{2}$ and a hummock tundra with a runoff rate of $6-12 \mathrm{l} / \mathrm{s} / \mathrm{km}^{2}$ (Fig. b). Within the flat part, upland and lowland bogs were mapped, the flow rates lower than $6 \mathrm{l} / \mathrm{s} / \mathrm{km}^{2}$.

Total dissolved solids (TDS) of surface waters showed areas with potential contribution of intrapermafrost and subpermafrost waters (Fig. c). Found groundwater spring with a TDS of more than $3 \mathrm{~g} / \mathrm{l}$ were not included for further analysis and mapping.

Three areas of the potentially different water sources were identified within the Ugolnaya-Dionisia River basin (Fig. d). Area I refers to the mountain tundra landscapes. We suggest that the dominant water sources in area I are condensation, snow meltwater from snowfields and precipitation. Water sources in the area II are also not typical for the lowland tundra. They are precipitation, deep groundwater and suprapermafrost groundwater formed by melting of seasonal ice in the active layer. The contribution of subpermafrost and suprapermafrost groundwater will be estimated by application of the mixing model. Area III dominates in the studied basin. Main water sources are suprapermafrost groundwater, snowmelt water and precipitation. Subarea IIIb is characterized by a slower water exchange due to the influence of upland and lowland bogs and a flat relief. 

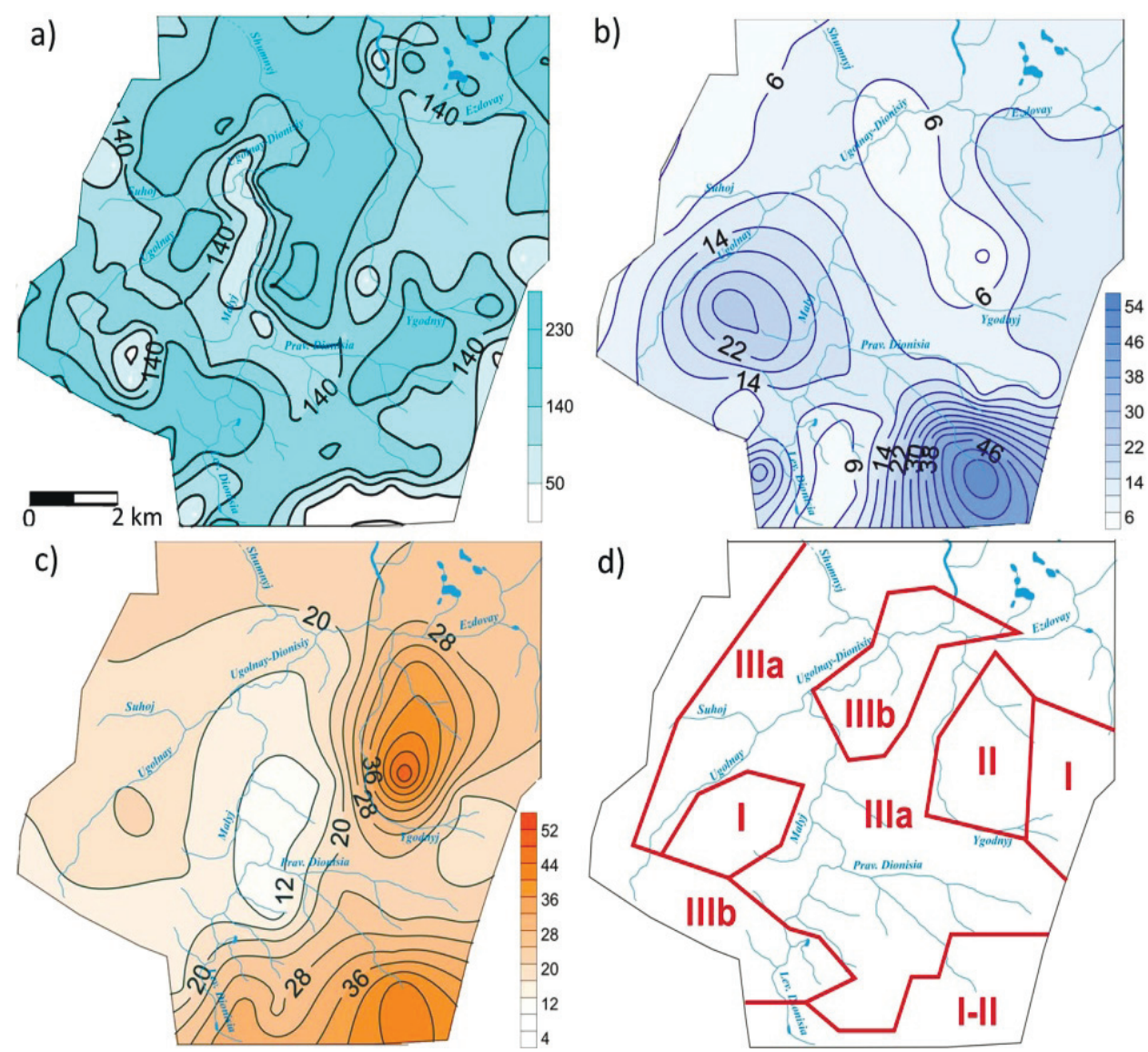

Fig. a) spatial distribution of water storages formed by melting of seasonal ice in the upper $30 \mathrm{~cm}$ of the active layer, mm, b) streamflow rate, $1 / \mathrm{s} / \mathrm{km}^{2}$ as of $1^{\text {st }}$ of July, c) total dissolved solids of river and creeks, $\mathrm{mg} / \mathrm{l}, \mathrm{d}$ ) zonation of the Ugolnaya-Dionisia River basin according to water sources, see I-III in the paper.

The significant role of suprapemafrost groundwater formed by ground ice melting in the active layer is confirmed by diurnal fluctuations of ground temperature and groundwater levels. Daily maximums of the active layer temperature are shifted from the highest temperature on the soil surface in the following sequence: $10 \mathrm{~cm}-3.5$ hours; $20 \mathrm{~cm}-8.3$ hours; $30 \mathrm{~cm}-10.6$ hours; $40 \mathrm{~cm}$ (frozen state) -13.1 hours. Groundwater levels in pits reached a maximum in the early morning of the next day in 14.8 hours, in creeks and rivers - in 15.9 hours. At the Ugolnaya-Dionisia River a high water level was observed from 07.00-09.00 p.m. to 04.30-07.00 a.m. A short-term water level decrease occurred at noon. The water temperature and level in the pits are in reverse phase: the maximum water level corresponds to its lowest temperature. Minimum temperatures occur at the beginning of a water level rise in creeks and at the beginning of its decline in a river. Moisture measurements of tundra soils showed the absence of diurnal fluctuations. Moisture at depths of 20-30 cm evenly increased in depressions and decreased at uplands. It is associated with a fluctuation of suprapermafrost water table. Additional observations in September 2019, when seasonal thawing depth reached 50-55 cm, also showed the absence of diurnal fluctuations in water levels in pits and creeks. 


\section{Conclusion}

Field study at the Ugolnaya-Dionisia river basin provided new data to describe dominant river water sources in the first half of summer period at the margin between plain and mountains under the subarctic sea climate conditions. Seasonal thawing depth and ground ice of the active layer significantly influence the river runoff in low tundra and bog landscapes. A simultaneous increase in the seasonal thawing depth, decrease in the ground ice content and decrease in river discharge during 10 days from 1500 to 163 1/sec suggest important contribution of suprapemafrost groundwater formed by ground ice melting in to the river.

The reported study was funded by RFBR, project No 18-05-60036.

\section{References}

1. O. D. Tregubov, Bull. of the North-East Scientific Center, 4, 20-27 (2010)

2. D. V. Magritskii, E. S. Povalishnikova, N. L. Frolova, Arctic and Antarctica, 3, 61-96 (2019)

3. N. L. Frolova, D. P. Nesterenko, N. V. Shenberg, Moscow Un. Bull. Ser. 5, Geogr., 6, 8-16 (2010)

4. A. N. Fedorov, P. P. Gavriliev, P. Y. Konstantinov, T. Hiyama, Y. Iijima, G. Iwahana, Eastern Siberia, Ecohydrol., 7, 188-196 (2014)

5. L. S. Lebedeva, Cand. geogr. sci. diss. Abstr., 22 (2018)

6. N. L. Tananaev, O. M. Makarieva, L. S. Lebedeva, Geophys. Res. Lett., 43(20), 10764-10772 (2016)

7. V. E. Glotov, Izv. of RAS SamSC, 18, 326-330 (2016)

8. J. C. Koch, C. P. Kikuchi, K. P. Wickland, P., Water Resour. Res. 50, 8141-8158 (2014)

9. W. L. Quinton, J. L. Baltzer, Hydrogeol. J., 21, 201-220 (2013)

10. D. Tetzlaff, J. Buttle, S. K. Carey, K. McGuire, H. Laudon, C. Soulsby, Hydrol. Processes, 29, 3475-3490 (2015)

11. M. A. Nuteveket, O. D. Tregubov, K. K. Uyagansky, Pros. 3th Int. Conf. "Vinogradov Readings. Facets of hydrology", (S-Petersburg, 28-30.03.18), 141-146 (2018) 